\title{
Impact of Packaging on Consumer Buying Behavior: A Study made on Millennial of Karachi
}

\author{
Muhammad Ahmed Soofi Desai \\ Sindh Madressatul Islam University \\ Mohammad Fazal Qureshi \\ ILMA University \\ Shaista Fazal \\ ILMA University
}

\begin{abstract}
The aim of this research is to identify the relation of product packaging on consumer's buying behavior of millennial of Karachi. The objective of this research is to add information in the existing research work which is done in packaging and how it influences the purchase behavior and then decision of the millennial of Karachi. The purpose of the research is to study those factors that can be use by the companies for driving the success of packaging style. This study will also explore the relations between different variables of packaging with consumer behavior. The dependent variable here in the study is consumer buying behavior while about five independent variables also used. This research is the brief overview of some important factors that can influence the purchase decision. The data used in the research is primary that will be collected from the millennial of Karachi through questionnaires (instruments) and then analyzed on SPSS software. The sample size is 311 which are aged between 15 and 40. After analyzing the data, the observations indicate that how much packaging is one of the most important factors for product that can influence the buying behavior especially of millennial. The changing trend and consumer's life style pattern is increasing the influence in packaging. The color, material of packaging, wrapper design and innovation also played an important role in consumer's purchase decision. Nowadays, the packaging color and design is also used as a medium of communicating the message to consumer. In last, the implication of the study with some future recommendations and research limitation with future gap has also been provided for exploring the new concept in the topic.
\end{abstract}

Keywords: Product color, packaging, Material, Size, Innovation, Label and Consumer Behavior.

1._desaimohammadsufi@gmail.com

2. fazalqureshi502@gmail.com

3.shaista70@gmail.com

Page | 109 


\section{INTRODUCTION}

Nowadays marketers are using different mediums to bombard the marketing stimuli on consumers that can influence their purchase decision. According to Keller (2008), while doing shopping, consumer eye passed through from about 20,000 products in the time of only 30 minutes but here the role of point of differentiation is played by packaging which differentiate it from the variety of similar products and boosts the consumer decision (Wells, Farley \& Armstrong, 2007). Now packaging is used a tool of promotional activities and it is the cheapest source for BTL activities and become the essential tools for marketers. The new generation of 21 st century carefully looks for product, look at everything and then purchase it. However, the time pressure will also influence the purchase decision some time as well.

\section{Background}

Traditionally, the role of packaging is only limited to the protection of the product from external environment but as the time passed, the marketers used this also as a tool of marketing and involve the packaging in their basket of boosting up of sales. The first tangible thing that is notice by the consumer while doing shopping is the packaging of the product. The packaging differentiates the product from other competing brands and hence, now companies have developed a proper team for designing a good packaging of products. The material of packaging, shape, size colors etc. all are now considered as a factor that can influence the consumers respond about the product. The past available information, consumer preference, and actions provide the reflection of consumer respond on packaging. All companies are now very much interested in observing the consumer's behavior. By stimulating the feelings of consumer, the marketer's main objective is to influence the purchase decision. Researches indicate that most of the times, consumers mostly go through the unplanned shopping rather than preplanned shopping. Hulten believe that about $70 \%$ of the consumers purchases are done at point of purchase. As a result, it is necessary for them to look for the solutions which can bring down this feeling of consumer

\section{Research Objectives}

The main objective of this research is to find the impact of important elements of color packaging that affects the consumer buying behavior. Therefore, the key objectives of this research paper are

- To determine the impact of components of packaging on consumer buying behavior

- To determine the effect of packaging on buying decision

- To determine the effect of each components of packaging on buying behavior with respect to consumer mood

- To detect the elements which should be prominent in packaging while designing to attract consumers?

\section{Scope}

Packaging is the outer view of the product which is lively seen by the consumer. The first thing that can reflect the product is the packaging and can play a very 
major role in purchasing decision. In Pakistan, the generation of millennials is very much conscious about the product. The advertisement helps marketers to bring the consumer till the point of purchase, but the packaging is the component which results in purchase decision. Many marketers are now focusing on product packaging and they are now very much aware about this strategy. So, this research will help them to identify that which component of packaging is important of consumer in purchase decision of millennials of Karachi. This research will also provide a secondary data for the future researchers to work and explore more components that can affect the buying decision.

\section{Research Limitation}

The study is limited to the daily life products or formerly known as Fast Moving Consumer Goods (FMCGs) products. The target populations are also limited to millennials of Karachi. So, the limitation of this study is the FMCGs or daily life products which are specially targeting the millennials of Karachi and results indicate the output of the target population towards the targeted products and also limited to the consumer mood.

\section{Research Gap}

According to Mazhar et al. (2015) stated that packaging is nowadays playing the role of success factor. There is still much gap and researches are need on this topic by focusing on other marketing dimensions. Research can be made on this topic by using different moderators or by adding more variables. The researcher who want to do research on packaging and influence on buying decision can also conduct this research in local region with local products as the psychological factor of every human being is different and varies from regions, cultures, religions etc. (Mohebbi, 2014). The study can also be made on hurdles of technological implication in packaging that which possible it can be solved and use of technological can be used to produce intelligent packaging. (Heising, Dekkar, Bartels \& Van Boekel, 2014). Packaging of elements is now completely transformed from traditional approach. Now it becomes a multi dimension factor. It telecast the information about the product as well as company and used as a communication mean between consumer and company with also performing the function of shield of protection from external environment (Silayoi\&Speece, 2007). The researchers must realize this factor and try to explore new concepts in packaging and consumer decision process (Zekiri\&Hasani, 2015). Now the consumer purchases the product after touching it, feels it and then studied the labelling of product. Consequently, the buying decisions are influenced by the labelling and packaging of product with role of some other factors (Ahmed et al., 2013).

\section{Research Question}

The following research questions tried to be answered in this research paper:

- What is the impact of packaging of product on consumer buying behavior targeting the millennials of Karachi?

- How different components of packaging are important in consumer buying process targeting the millennials of Karachi.

- Which components of packaging effects the consumers buying behavior of millennials of Karachi most. 


\section{LITERATURE REVIEW}

The importance of Packaging can be reflecting from the four Ps of marketing, which are also modified and one more P i.e. packaging is also introduced in that. Consumer can be attracted towards the product through advertisement and promotions but the last decision which forced him to buy is product packaging which is internally made by perception of product packaging in consumer's mind (Ahmed, Billo\& Lakhan, 2012). It also helps in differentiation of product from others. According to Saeed, Lodhi et al. (2013), packaging reflects the brand image and this brand image will help the consumer in taking the purchase decision. The study they conducted also revealed the information that brand image has no directly link with purchase decision but when other elements were added, it showed a positive image.

Marketing activities are now also transformed and now product packaging has been added in the basket of promotional activities (Shruti, 2014). The unique features of product packaging stimulate the purchase decision of consumer and for a long period of time, consumer will not forget about the product. So, whenever the consumer goes for shopping, the unique feature of packaging help him in purchase decision if even the name of product is forgotten by the consumer. Deliya \& Parmar (2012) studied that packaging is now even helping the organization in increasing their revenue streams. The cost of good packaging is now allowed the companies to charged premium pricing for the product.

\section{Theoretical Review}

\section{Theory of Attractive Quality}

"Theory of Attractive Quality" is a very well-known theory given by the Professor Kano and his research associates. After the theory of Herzberg two factor theories, Professor Kano in 1984 has given another theory in the field of management science. This theory emphasizes to look deeply and with different angles in all aspects to understand that who the customer is memorizing and building the image of any product. This theory provides the bridge between the customer satisfaction level and perceive value by providing the quality features. There are five dimensions to measure the perceive quality attributes and these were clearly describing by the Kano in his theory. It also describes that how the perceive value from customer side changes from satisfaction to dissatisfaction.

The degree of packaging is very much influence by the theory of Attractive Quality of Professor Kano. It describes the relationship between the packaging and the quality in three different aspects i.e. before, during and after. The operationalization of this theory in field of marketing regarding to packaging helps the marketers to understand that why being providing the same quality overtime, the customer switch towards others. It describes the role of packaging and importance of packaging regarding to the customer satisfaction. When the costumer sees the attractive quality of packaging, the stimulus response, and ultimately, this will lead to build a strong brand image resulting in customer satisfaction. 


\section{Theoretical Framework।}

Independent Variables

\section{Packaging Material}

Packaging Color

Innovation

Packaging Size

Information or label

\section{Consumer Buying Behavior}

The behavior of the purchasers is based on their preferences, attitude and decision concerning about obtaining the product. The consumer buying decision is comprises of five steps (Lake, 2009). Researchers have identified and many consumer behavior books including Schiffman have provided these five steps. The five steps area of decision making process is as follows:

1. The consumer is firstly identified his need or problem.

2. In second the consumer tries to find out the relevant information about his need from primary or secondary sources.

3. The third step is evaluation stage in which he evaluates the alternative and information he collected.

4. The fourth step involves the purchase in which the product is physically belongs to the consumer.

5. In last stage, this is the feedback stage that whether the product fulfil the need and satisfy the consumer or not.

Lynn Metcalf (2012) suggested that the consumer buying behavior is the factor that changes very rapidly. Sometimes it is according to the need and sometimes, the mood of the individual also affected the purchase decision. So, the component of feeling after touching the product and observe, it will create an impulse buying behavior for consumer.

Ulrich R. Orth (2009) identified that consumer predict the product from the packaging of product. In his study, found that the adult people are also very much concern about the packaging. He found that besides a good quality of product, a beautiful packaging is also necessary to attract the consumer.

\section{Packaging Material}

In this century people are very much observant and required a proper and good packaging material. Thomas (2011) identified that material of packaging reflects the expectations of consumers by the company. It also reflects the hygienic component Page | 113 
of the product. Baik (2011) studied that for the niche market product, the material used in packaging played a vital role. To communicate the message and product targeting the upper class should be pack in the good packaging material that can be feel by the consumer. Saeed, Lodhi et al. (2013) agreed that now only product packaging is not enough. Now the consumer looks for color and the packaging material also and then take the decision of purchase the material used in the packaging define the class of product and the targeted segment of the product.

\section{Packaging Color}

Some studies showed that due to the proper usage of color, the buying intentions of consumer also changed, result in changing the behavior from ignoring to starting of purchase of product. In the study conducted by the Behzad (2014), describe the importance of color in packaging of product. The scheme of color on packaging itself a source of knowledge and communication for consumer and according to Singh (2006), about $62 \%$ to $90 \%$ of consumer can be identified the product on basis of color only. The colors help the product in becoming the prominent with the side products and make it the dominant in the place. Labrecque, Patric\& Milne (2013), identified that people are very much interested in the colors of packaging of product. They associate the color of packaging with their past feelings, thoughts and choices.

\section{Innovation}

Innovation in packaging can add up some additional value in the packaging as well as in product also. In new millennium, the role of technology is completely changed and now it is used in all fields. The packaging industry is now using different innovative techniques for delivering the best to the products and makes them prominent (Noorani\&Setty, 2007).Borin et al. (2011) identified that now customers are very much interested in the technological usage because the development of environmental friendly campaigns realized the importance of ecofriendly wrapping. The study also finds that the people are very much concern and those product wrappers which are harming the environment in making stage, processing stage or output stage, consumer usually are now quitting the product and switching to other. Nowadays, the unique selling proposition is not only limited to the product but also link with the features and attributes of the products (Rundh 2005).

\section{Packaging Size}

Packaging size should be convenient and easy to store or handle. The study identifies the phenomena resulting that about $55 \%$ of consumer left the brands after attracting towards the product, only due to the creepy packaging size. The study also disclosed that about $36 \%$ people change the brand per year only due to the creepy size of packaging.According to Rundh (2005), now the process of innovation had completely changed the dimension of size of product. The marketers now conducting different researches to make the packaging size more innovation. The products targeting the upper class should be pack with the size targeting those categories i.e. weight of purchase decision and for lower class; it must be in frequency of purchase size.

\section{Label or Information}

The label is considered as the language of product which is spoken by the product 
itself. It tells the consumer about the features of product, the purpose of product, function of product etc. besides providing the information about product name, organizational name, place, expiry date, manufacturing date etc. (Neeta \& Sudha, 2014). The labelling on packaging of product can force the consumer to buy in bulk quantity and labelling is one of key factors which can influence the consumer buying decision (Saeed, Lodhi et al, 2013). At the point of sale where the consumer purchase product, packaging played a vital role here (Silayoi\&Speece, 2004). The consumer was in hurry and he took decision by seeing the product packaging only with the label information on the packet. This will result in maintain the long-term sustainable and profitable relationship between the consumer and influenced their buying behavior.

\section{Research Hypothesis}

H1: Material of Packaging has significant impact on customer buying behavior.

H2: Packaging color has significant impact on customer buying behavior.

H3: Packaging Innovation has significant impact on customer buying behavior.

H4: Packaging size has significant impact on customer buying behavior

H5: Information \& labelling on packaging has significant impact on customer buying behavior.

\section{METHODOLOGY}

\section{Research Design}

Causal research is used for testing the cause and effect between the variable. Here, the researcher is also going to test the cause and effect of independent variable on dependent variable.

\section{Research Method}

Quantitative research method is used in this research as quantitative research requires an instrument to collect data from respondent. Here we check the hypothesis and find out the relationships. The reliability is very important factor in quantitative research because it will give you the output that the respondent you have selected is from right target segment. The responses ask by the respondent are mostly closed which can be converted into numeric value for SPSS test.

\section{Sampling Technique}

In this research, convenience sampling method is used to obtain data. As every person is somehow involve in shopping for different type of product, and that can influence his buying behavior, so it is easy and convenient method to collect the data.

\section{Sample Size and Population}

The sample size of the study is 311 respondents of Karachi with age limit of 15 years to 40 years as my target population is millennials.

\section{Instrument used for Data collection}

Instrument has been adapted to measure different variables. Like for example, the instrument designed by Silayoi\&Speece (2004) is used to measure the variables 
which consists of 4 to 6 items each. Instruments used in the research are measured on five-point Likert scale ( $1=$ Strongly Agree \& 5=Strongly Disagree). Reliability analyses have also been conducted to test the reliability of instrument for the region. All precautions had been taken in data collection to minimize the sampling error. The data collected has been analyzed through SPSS.

\section{Scale and Measure}

A five-point Likert-type scale was used to measure these items, ranging from "Strongly Agree" (1) to "Strongly Disagree" (5). The six variables each for the at least four items 'color, 'material, 'size', 'information and label' and 'innovation' were adopted from Silayoi\&Speece (2004) .

\section{Results}

Following information is the general overview of our demographics. Gender demarcation consist of $193(62 \%)$ males and $118(38 \%)$ females. $63 \%$ of respondents lie between the age bracket of 21 to 30 years while $18 \%$ are under 21 years old whereas rest of them are above 30 years old. In terms of marital status, $271(87 \%)$ were single and $40(13 \%)$ were married. In terms of qualification $202(65 \%)$ are undergraduate, $103(33 \%)$ are graduate while only 6 respondents are post graduate or $\mathrm{PhD}$ students. approx 70\% respondents have monthly income from Rs. (2600035000).

\section{Descriptive Statistics}

Given below in Table 1 it is shown that construct Packaging size (Mean=2.72, S.D. $=1.45$ ) has lowest value of skewness (.375), Packaging material (mean. $=$ $2.5, \mathrm{SD}=1.3$ ) has the highest skewness $(0.74)$. Kurtosis is negative for all items. Packaging size $($ Mean. $=2.72$, S.D. $=1.45)$ has highest value i.e. 1.79 and the lowest value is for Packaging material which is (Mean.=2.5, S.D =1.3) is 1.31. All the construct value lies between \pm 3.5 , hence, the data is normally distributed. (Hair Jr. et al, 2010).

To ascertain normality of the data and to check the univariate validity, the descriptive statistics test has been run in SPSS 22, which is summarized in Table 1.

\begin{tabular}{lllll}
$\begin{array}{l}\text { Table 1 } \\
\text { Descriptive Analysis }\end{array}$ & \multicolumn{3}{l}{} \\
\hline & Mean & Std. Dev. & Skewness & Kurtosis \\
\hline Consumer Buying Behavior & 2.7701 & 1.363 & .421 & -1.781 \\
Packaging Material & 2.5119 & 1.305 & .746 & -1.313 \\
Packaging Color & 2.7293 & 1.390 & .381 & -1.688 \\
Innovation & 2.7125 & 1.313 & .541 & -1.617 \\
Packaging Size & 2.7245 & 1.452 & .375 & -1.797 \\
Information or Label & 2.7293 & 1.384 & .379 & -1.747 \\
\hline
\end{tabular}

\section{Reliability of the constructs}

The reliabilities were established in context with our research and the respondents. Table 2 has the summarized results of the tests. 
IBT Journal of Business Studies (IBT-JBS) Volume 15 Issue 2 December 2019

Table 2

Reliability of the Constructs

\begin{tabular}{cllll}
\hline Constructs & $\begin{array}{l}\text { Cronbach's } \\
\text { Alpha }\end{array}$ & $\begin{array}{l}\text { No } \\
\text { of items }\end{array}$ & Mean & $\begin{array}{l}\text { Std. } \\
\text { Dev. }\end{array}$ \\
\hline Packaging Material & 0.799 & 5 & 2.5119 & 1.305 \\
Packaging Color & 0.847 & 5 & 2.7293 & 1.390 \\
Innovation & 0.821 & 5 & 2.7125 & 1.313 \\
Packaging Size & 0.862 & 6 & 2.7245 & 1.452 \\
Information or Label & 0.857 & 5 & 2.7293 & 1.384 \\
Consumer Buying Behavior & 0.872 & 6 & 2.7701 & 1.363
\end{tabular}

The above Table 2 shows that the reliability of Packaging in consumers buying behavior is the highest value $(\alpha=.872$, Mean. $=2.7$, S.D. $=1.36)$ while the reliability for Packaging material is the lowest value $(\alpha=.799$, Mean.=2.7, S.D. $=1.39)$. The Cronbach's alpha for all other instrument including dependent and independent variables is 0.8 .

\section{Exploratory Factor Analysis (EFA)}

Exploratory factor analysis was used to disclose the latent variables and their relations with the constructs. Table 3 has the summarized results of the test.

Table 3

EFA for the constructs

\begin{tabular}{lcllll}
\hline Construct & $\begin{array}{l}\text { Original } \\
\text { Items }\end{array}$ & $\begin{array}{l}\text { Kaiser } \\
\text { Meyer } \\
\text { Olkin }\end{array}$ & $\begin{array}{l}\text { Barley Test } \\
\text { of Sphercity } \\
\text { at P=.000 }\end{array}$ & $\begin{array}{l}\text { Cumulative } \\
\text { Factor } \\
\text { loading }\end{array}$ & $\begin{array}{l}\text { Item } \\
\text { Retained }\end{array}$ \\
\hline CBB & 6 & 0.902 & 2939 & $89.9 \%$ & 6 \\
Packaging Material & 5 & 0.894 & 2238 & $90.0 \%$ & 5 \\
Packaging Color & 5 & 0.893 & 2593 & $92.2 \%$ & 5 \\
Innovation & 5 & 0.916 & 2020 & $88.9 \%$ & 5 \\
Packaging Size & 6 & 0.925 & 3010 & $90.8 \%$ & 6 \\
Information or Label & 5 & 0.916 & 2048 & $89.3 \%$ & 5
\end{tabular}

We have applied Principal Factor Analysis on our constructs with Varimax rotation. The KMO of all the constructs has greater than 0.7 and all the constructs fulfilling the requirements of convergent validity because all the constructs have total variance explained is greater than $40 \%$ and convergent validity has the requirement that total variance explained should be greater than 40\%(Cline, 2010, Hair Jr., 2008).

\section{Correlation Analysis}

We used correlation analysis to find whether there is any relationship b/w our variables or not and also we want to check is there multi-co linearity exists among the variables or not (Bryman \& Bell, 2005). The following table shows the results of correlation.

Table.4

Summarized Correlation Results

\begin{tabular}{|c|c|c|c|c|c|c|}
\hline & $\mathrm{Cbb}$ & $\mathrm{Pm}$ & $\mathrm{Pc}$ & $\mathrm{Inn}$ & Ps & Inf \\
\hline $\mathrm{CBB}$ & 1 & & & & & \\
\hline
\end{tabular}


IBT Journal of Business Studies (IBT-JBS) Volume 15 Issue 2 December 2019

\begin{tabular}{|c|c|c|c|c|c|c|}
\hline Packaging Material & 0.565 & 1 & & & & \\
\hline Packaging Color & 0.739 & 0.642 & 1 & & & \\
\hline Innovation & 0.818 & 0.650 & 0.860 & 1 & & \\
\hline Packaging Size & 0.765 & 0.685 & 0.941 & 0.904 & 1 & \\
\hline Information or Label & 0.818 & 0.662 & 0.852 & 0.941 & 0.886 & 1 \\
\hline
\end{tabular}

The output of Table 4 indicates that all the relationships were significant at a level of 0.05 (2-tailed). The Correlation of Innovation (Mean. $=2.725$, S.D. $=1.452, \mathrm{~N}=311$ ), $\mathrm{p}=0.0<0.05$, has highest value (strongest) while the lowest valuewas of Packaging Material (Mean. $=2.729$, S.D. $=1.390, \mathrm{~N}=311), \mathrm{p}=0.0<0.0$. Moreover,Correlation conveys that the variables are differentiable, unique and distinguishing (Hair Jr.et al, 2010).

\section{Overall Regression Model Test}

Table 6 summarized the version of regression model for overall model of the research study. The hypothesis developed that the characteristics of the independent variable of packaging (Color, Material, Label, Size and Innovation) significantly impact the consumer's buying behavior towards packaging was tested through regression model.

Furthermore, the regression results also indicate that how Color, Material, Label, Size and Innovation of packaging impact the consumer's buying behavior, was tested also through regression test whereas label and innovation have the impact on consumer buying (See Table 6).

The output of the regression test for the overall model of study indicates that the predictors Label and Inovation has the assosiation with consumer buying behavior explain $68.5 \%$ of the variance $(|\mathrm{R} 2|=0.685, \mathrm{~F}(5,305)=135.9, \mathrm{p}<0.05)$, which according to rule of thumb if it is greater than 0.5 so they have stronge correlation.

Table 6

Summarized Regression Resulrs

\begin{tabular}{|c|c|c|c|c|c|}
\hline \multirow{2}{*}{ Variables } & \multicolumn{2}{|c|}{$\begin{array}{l}\text { Unstandardized } \\
\text { Coefficients }\end{array}$} & $\begin{array}{l}\text { Standardized } \\
\text { Coefficients }\end{array}$ & \multirow[t]{2}{*}{$\mathbf{T}$} & \multirow[t]{2}{*}{ Sig. } \\
\hline & B & Std. Error & Beta & & \\
\hline (Constant) & 0.421 & 0.108 & & 3.894 & 0.000 \\
\hline Material & 0.015 & 0.046 & 0.015 & 0.330 & 0.742 \\
\hline Color & 0.074 & 0.093 & 0.075 & 0.798 & 0.425 \\
\hline Innovation & 0.401 & 0.109 & 0.386 & 3.684 & 0.000 \\
\hline Size & -0.011 & 0.108 & -0.012 & -0.106 & 0.915 \\
\hline Information & 0.385 & 0.097 & 0.391 & 3.979 & 0.000 \\
\hline
\end{tabular}

Note: Dependent Variable: Consumer Buying Behavior.

Material: The Ho is that Packaging material has significant impact on customer buying behavior which is measured from Regression Analysis. 
IBT Journal of Business Studies (IBT-JBS) Volume 15 Issue 2 December 2019

Table 7

Summarized Regression Results

\begin{tabular}{|c|c|c|c|c|c|c|}
\hline \multicolumn{7}{|c|}{ Coefficients } \\
\hline \multirow{2}{*}{\multicolumn{2}{|c|}{ Model }} & \multicolumn{2}{|c|}{$\begin{array}{l}\text { Unstandardized } \\
\text { Coefficients }\end{array}$} & \multirow{2}{*}{$\begin{array}{c}\text { Standardized } \\
\text { Coefficients } \\
\text { Beta }\end{array}$} & \multirow[b]{2}{*}{$\mathrm{t}$} & \multirow[b]{2}{*}{ Sig. } \\
\hline & & B & Std. Error & & & \\
\hline \multirow[t]{2}{*}{$\overline{1}$} & (Constant) & 1.289 & .139 & & 9.290 & .000 \\
\hline & Material_Mean & .590 & .049 & .565 & 12.024 & .000 \\
\hline
\end{tabular}

a. Dependent Variable: CBB_Mean

The result of our statistical technique specifies that the independent variable describes $32 \%$ of the variance with $\mathrm{r} 2=0.319$ whereas Beta shows the effect of independent variables on dependent variables that is .565 which according to the rule of thumb has significant relation and high impact on dependent variable.

Color: The Ho is that Packaging color has significant impact on customer buying behavior which is measured from Regression Analysis.

Table 9

Summarized Regression Results

\section{Coefficients}

\begin{tabular}{|c|c|c|c|c|c|c|}
\hline \multirow[b]{2}{*}{ Model } & & \multicolumn{2}{|c|}{$\begin{array}{l}\text { Unstandardized } \\
\text { Coefficients }\end{array}$} & \multirow{2}{*}{$\begin{array}{c}\text { Standardized } \\
\text { Coefficients } \\
\text { Beta }\end{array}$} & \multirow[b]{2}{*}{1} & \multirow[b]{2}{*}{ Sig. } \\
\hline & & B & Std. Error & & & \\
\hline \multirow[t]{2}{*}{$T$} & (Constant) & .793 & .115 & & 6.882 & .000 \\
\hline & Color_Mean & .725 & .038 & .739 & 19.265 & .000 \\
\hline
\end{tabular}

a. Dependent Variable: CBB Mean

The result of our statistical technique specifies that the independent variable describes $54 \%$ of the variance with $\mathrm{r} 2=0.546$, whereas Beta shows the effect of independent variables on dependent variables that is .73 which according to the rule of the thumb has significant relation and high impact on dependent variable.

Innovation: The Ho is that Packaging Innovation has significant impact on customer buying behavior which is measured from Regression Analysis.

Table 9

Summarized Regression Results

\begin{tabular}{|c|c|c|c|c|c|c|}
\hline \multicolumn{7}{|c|}{ Coefficients } \\
\hline \multirow[b]{2}{*}{ Model } & & \multicolumn{2}{|c|}{$\begin{array}{l}\text { Unstandardized } \\
\text { Coefficients }\end{array}$} & \multirow{2}{*}{$\begin{array}{c}\text { Standardized } \\
\text { Coefficients } \\
\text { Beta }\end{array}$} & \multirow[b]{2}{*}{$\mathrm{t}$} & \multirow[b]{2}{*}{ Sig. } \\
\hline & & B & Std. Error & & & \\
\hline$\overline{1}$ & (Constant) & .467 & .103 & & 4.551 & .000 \\
\hline & Innovation_Mean & .849 & .034 & .818 & 24.958 & .000 \\
\hline
\end{tabular}

a. Dependent Variable: CBB_Mean

The result of our statistical technique specifies that the independent variable describes $66 \%$ of the variance with $\mathrm{r} 2=0.668$, whereas Beta shows the effect of independent variables on dependent variables that is .818 which according to the rule of the thumb has significant relation and high impact on dependent variable.

Page | 119 
Size: TheHo is that Packaging size has significant impact on customer buying behavior which is measured from Regression Analysis.

Table. 10

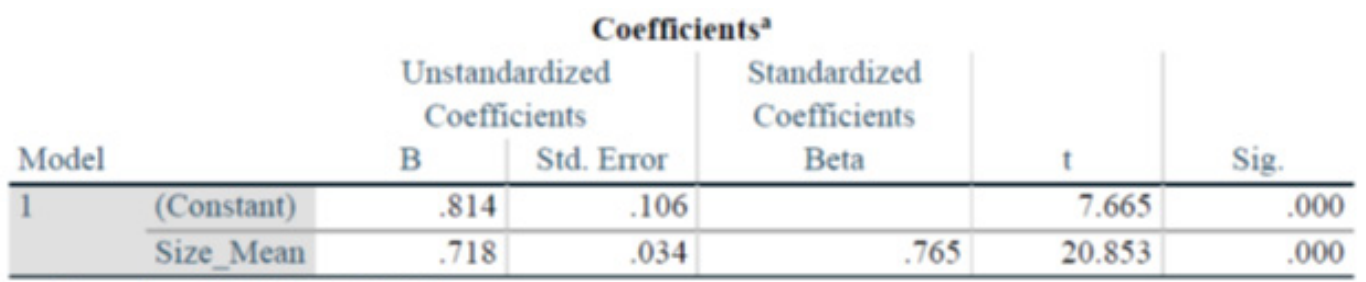

a. Dependent Variable: CBB Mean

The result of our statistical technique specifies that the independent variable describes $58 \%$ of the variance withr $2=0.585$, whereas Beta shows the effect of independent variables on dependent variables that is .765 which according to the rule of thumb has significant relation and high impact on dependent variable.

Label: The Ho is that Packaging label has significant impact on customer buying behavior which is measured from Regression Analysis.

Table 11

Summarized Regression Results

\begin{tabular}{|c|c|c|c|c|c|c|}
\hline \multicolumn{7}{|c|}{ Coefficients ${ }^{a}$} \\
\hline \multirow[b]{2}{*}{ Model } & & \multicolumn{2}{|c|}{$\begin{array}{l}\text { Unstandardized } \\
\text { Coefficients }\end{array}$} & \multirow{2}{*}{$\begin{array}{c}\text { Standardized } \\
\text { Coefficients } \\
\text { Beta }\end{array}$} & \multirow[b]{2}{*}{$t$} & \multirow[b]{2}{*}{ Sig. } \\
\hline & & B & Std. Error & & & \\
\hline \multirow[t]{2}{*}{1} & (Constant) & .572 & .099 & & 5.798 & .000 \\
\hline & Label_Mean & .805 & .032 & .818 & 24.961 & .000 \\
\hline
\end{tabular}

a. Dependent Variable: CBB Mean

The result of our statistical technique specifies that the independent variable describes $67 \%$ of the variance with r2 $=0.668$, whereas Beta shows the effect of independent variables on dependent variables that is .818 which according to the rule of thumb has significant relation and high impact on dependent variable.

\section{DISCUSSION AND CONCLUSION}

This research is all about that packaging as it has very vast impact on consumer's behavior as it is the leading channel through which a customer can attract or avoid the product. Many packaging elements will be empirically tested which shows that in this era it has extreme effect on purchaser's preferences and on their selection of the product. It helps companies to differentiate their product from the rivalry and also help customers in identification of the product. For this reason, the elements are classified in different variables. Now a day's people have high acceptance for new and creative packaging through which they can more easily understand the product and analyze it.

In a nut shell, the test which will be going to applied in future on this study will 
help to understand each variable and factor influence on consumer buying decision and also explore the impact when consumer is in time pressure or doing impulse buying. In our study we study several variables which might affect packaging in attracting the customers. The study will also reveal the impact of the packaging and buying pattern when consumer is in good mood related to the FMCG product.

\section{Practical Implication}

This research result will help them out to know the output of the millennials of Karachi that what type of packaging they like. They mostly look for the environmental friendly packaging product. Technology has changed the world rapidly. Here how the innovation in packaging can help them with overcoming and exploring the concepts. The results are very helpful for new FMCGs companies who want to penetrate in market with the same target segment. The marketers can use the outputs of this research to make comparison with other target segmented output to provide the consumer with intermediate product packaging and helpful for increasing their product share in industry.

\section{Contribution in Literature}

The product packaging is become a hot topic for researchers to explore the new variables and concepts as now the industrial implication of packaging is become very important. Consumers want that when he takes the product, the packaging should be prominent that the others can easily guess the brand or product.

There are no or very few researches are carried out using consumer mood as moderator variable in packaging in Pakistan especially in Karachi. This research will add some new components in existing work of research on this topic. The packaging is clothes of the product: the beautiful the clothes, the better attraction product gets. The colors of packaging are also very important and play a vital role. The color should be selected by the marketers according to the product category. The color theory is already being develop for this person and it is very much link with the consumer psyche.

The role of packaging is now completely transformed from the traditional approach. The consumer who has no such buying intention towards the product, but due to the packaging, it will definitely be attracted towards the product and try it for at least one time. The new concept of customizing the wrapping is recently introduced. This concept reflects the importance of packaging as consumer buying is very much influence by emotional decisions. The rational part of consumer is only work after testing the product. But for the first time, if he decides, the emotional part will dominant and he purchase the product due to attractive packaging. The consumers after looking at packaging and seeing so much information, his purchase decision influence because of his emotional part dominant again and clarity he found on wrapper.

\section{REFERENCES}

Aaker, D. A., 1991, Managing Brand Equity, New York: The Free Press.

Aaker, D.A., 1996, 'Measuring brand equity across products and markets', California

Page $\mid 121$ 
Management Review 38(3), 102-121. http://dx.doi.org/10.2307/41165845.

Adam A.M. \& Ali. K., (2014), "Impact of Packaging Elements of Packaged Milk on Consumer Buying Behavior", International Conference of Marketing, IBAICM 2014.

Baik, S., (2011). "Package design management in SMEs", Diversity and Management, pp: 1-6.

Behzad, M., (2014), "The art of packaging: An investigation into the role of color in packaging, marketing, and branding", International Journal of Organizational Leadership pp. 92-102.

Bix, L., Seo, W., \& Sundar, R. P. (2013). The effect of color contrast on consumers' attentive behaviors and perception of

fresh produce. Packaging Technology and Science, 26, 96-104.

Borin, N., Cerf, D.C., \& Krishnan, R. (2011). Consumer effects of environmental impact in product labeling, Journal of Consumer Marketing, 28(1), pp. 76-86.

Deliya, M.M. \&Parmar, B.J. (2012), 'Role of packaging on consumer buying behavior: Patan District', Global, Journal of Management and Business Research, Vol.12 (10), ISSN: 122-137.

Heising, J. K., Dekker, M., Bartels, P. V., \& Van Boekel, M. A. J. S. (2014). Monitoring the quality of perishable foods: Opportunities for intelligent packaging. Critical Reviews in Food Science and Nutrition, 54(5), 645-654.

Javed A., Javed S., (2015), "The impact of product's packaging color on customers' buying preferences under time pressure", Journal of Industrial Management Institute, Marketing and Branding Research 2(2015) 4-14.

Kauppinen-Räisänen, H. (2014). Strategic use of colour in brand packaging. Packaging Technology and Science, 27, 663-676.

Keller, K.L., 2009. Choosing Brand Elements to build Brand Equity. Strategic Brand Management. 3rd ed. Delhi: Dorling Kindersley. Pp.187-96.

Keller, Kevin L. (2008). Strategic Brand Management. New Jersey: Pearson Education.

Kotler, P. and Keller, K., (2011) Marketing Management (14th edition). London: Pearson Education.

Labrecque, L., Patrick, V. M., \& Milne, G. R. (2013). The marketers' prismatic palette: A review of color research and future directions. Psychology \& Marketing, 30(2), 187-202.

Lake, L. A. (2009). Consumer Behavior for Dummies. Indiana: Wiley Publishing, Inc.

Lynn Metcalf, J. S. (2012). A mixed-methods approach for designing market driven-packaging. Qualitative Market Research: An International Journal, 15 (3), 268-289.

ManijehBahrainizad, AzadehRajabi, "Consumers' perception of usability of product packaging and impulse buying: considering consumers' mood and time pressure as moderating variables", Journal of Islamic Marketing, https:// doi. org/10.1108/JIMA-04-2016-0030.

Mazhar, Daud, Bhutto \&Mubin., (2015). "Impact of Product Packaging on Consumers Buying Behavior: Evidence from Karachi”, Journal of Marketing and Consumer Research, ISSN 2422-8451 An International Peer-reviewed Journal, Vol.16, 2015.

Nawaz, A., Billoo, M. and Lakhan, A. A. (2012). Effect of Product Packaging in 
Consumer Buying Decision, Journal of Business Strategies, Vol.6, No. 2, pp 1-10, ISSN: 1993-5765.

Noorani, H.S., \&Setty, K. (2007). "Three Steps for Successful implementation of Sales Portals in CPG companies". International Journal of Retail and Distribution Management, Vol. 35, 746-749.

Raheem R., Vishnu P., Ahmed M., (2014), "Impact of Product Packaging on Consumer's Buying Behavior", European Journal of Scientific Research, Vol. 122, No 2, 2014.

Rundh, B. (2005). The Multi-faceted dimension of packaging: marketing logistic or marketing tool? British Food Journal, 107(9), 670-84.

Saeed, R., Lodhi, R.N., Mukhtar, A.M.J., Hussain, S., Mahmood, Z., and Ahmad, M., (2011). Factors Affecting Consumer Purchase Decision in Clothing Industry of Sahiwal, Pakistan., World Applied Sciences Journal, Vol: 24 (7): ISSN: 844-849.

Saeed, R., Lodhi, R.N., Rauf, A., Rana, M.I., Mahmood, Z., and Ahmed, N. (2013). Impact of Labelling on Customer Buying Behavior in Sahiwal, Pakistan, World Applied Sciences Journal, Vol: 24 (9), ISSN: 1250-1254.

Shah, S., Ahmed, A., \& Ahmad, N. A. W. A. Z. (2013). Role of Packaging in Consumer Buying Behavior. International Review of Basic and Applied Sciences, 1(2), 35-41.

Sharma, N., Sudha, R., (2014), International journal of enhanced research in educational development (IJERED), Vol.2, Issue 5, pp: 16-20, ISSN: 23208708.

Silayoi, P., \&Speece, M. (2007). The importance of packaging attributes: A conjoint analysis approach. European Journal of Marketing, 41(11), 1495-1517.

Silayoi, P. \&Speece, M. (2004), 'Packaging and purchase decisions: an exploratory study on the impact of involvement level and time pressure', British Food Journal.Vol.106(8), 607-628.

Singh, S. (2006). Current research development: Impact of color on marketing. Management Decision, 44(6), 783-789.

Thomas Sioutis, (2011). "Effects of Packaging design on consumer expectations of food product healthiness", AARHUS SCHOOL OF BUSINESS, Department of Marketing and Statistics, pp.5-6. 